\section{EDUCATION}

Research, Innovation and Solutions on-line ${ }^{(0)}$

\section{Electronic Journal of Research}

in Educational Psychology

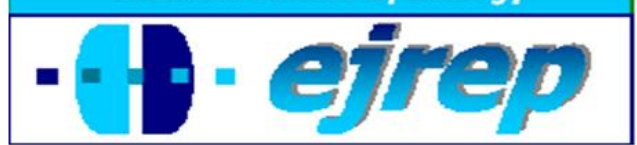

\title{
Does Gender Moderate Dimensional Comparison Effects in L1 and L2 Self-Concepts of Secondary Foreign Language Learners?
}

\author{
Günter Faber ${ }^{1}$ \\ ${ }^{1}$ Institute of Educational Psychology, Leibniz University, Hannover
}

Germany

Correspondence: Günter Faber, Dr.phil. Leibniz University Hannover, Institute of Educational Psychology, Schloßwender Str. 1, D-30159 Hannover. Germany. E-mail: faber@psychologie.uni-hannover.de 


\section{Abstract}

Introduction. With regard to the interal/external frame of reference model of academic selfconcept development the present study aimed at testing its theoretical assumptions within the verbal domain - namely to analyze the relations between achievement and self-concept in the native language German (L1) and the foreign language English (L2). Due to inconsistent research findings in this field the focus of analyses was on identifying differential patterns of dimensional comparison processes as they might depend on students' achievement level in both subject areas and on students' gender.

Method. Data were gathered in a sample of 256 ninth grade students from German inner-city grammar schools. For measuring students' self-concepts two subject-specific scales were used. For measuring their achievement in each language subject latest grades as well as teacher competency ratings were used. Relations among constructs were analyzed by means of a structural equation modeling approach including multiple group comparisons between the female and male subsample.

Results. No dimensional comparison effects could be demonstrated. Neither negative contrasting nor positive assimilation effects across both language subjects occured. Furthermore, multiple group comparisons of structural equation analyses lent strong support for the invariance model. Thus, despite significantly apparent achievement and self-concept differences between female and male learners in the L1 German gender did not moderate the relations between achievement and self-concept variables across both language subjects.

Discussion. In the female as well as in the male subsample self-concept formation in both language subjects appears to be mainly affected by social comparison effects. This finding not only confirms previous research results in the field, but also contributes to clarify the role of gender in the internal/external frame of reference model - concerning the issue of dimensional comparison within the verbal domain, at least.

Keywords: Verbal self-concepts, dimensional comparison effects, internal/external frame of reference model, gender, foreign language learning, EFL context.

Received: 09/06/12 Initial acceptance: 09/15/12 Final acceptance: 11/03/12 


\section{¿El género modera efectos dimensionales de comparación en el auto-concepto $L 1$ y $L 2$ de aprendices de un idioma extranjero?}

\section{Resumen}

Introducción. Con respecto a la estructura interna/externa del modelo de referencia de desarrollo del autoconcepto académico, el presente estudio pretendió poner a prueba los supuestos teóricos dentro del dominio verbal, a saber, para analizar la relación entre los logros y el autoconcepto en la lengua nacional alemana (L1) y la lengua extranjera Inglés (L2). Debidoos resultados de investigación inconsistentes en este campo, el foco de análisis fue compoarar e identificar patrones diferenciales dependientes del nivel de logro de los estudiantes en las dos sub áreas lingüísticas de proyecto y del género de los estudiantes.

Método. Los datos fueron recogidos en una muestra de 256 estudiantes de noveno grado de alemán de diferentes centros. Para la medición del autoconcepto de los estudiantes en las dos materias específicas se utilizaron escalas. Para medir su rendimiento en idioma de cada materia se utilizaron las últimas calificaciones, así como la puntuación de la competencia de los profesores. Las relaciones entre las construcciones fueron analizadas por medio de un modelo de ecuaciones de enfoque estructural, incluyendo comparaciones múltiples entre grupos de la submuestra del género de los alumnos.

Resultados. No se observaron efectos de comparación dimensionales. No aparecieron efectos de contrate nio positivos ninegativos en las dos asignaturas de lengua estudiadas. Por otra parte, las comparaciones múltiples grupales de análisis de ecuaciones estructurales prestó decidido apoyo a la invariancia del modelo. Por lo tanto, a pesar de los logros evidentes y significativos, las diferenciasde autoconcepto entre los alumnos de ambos sexos en el L1 alemán no moderar las relaciones entre los logros y las dos asignaturas de lengua nacional y extranjera.

Discusión. En las alumnas y en los alumnos, la formación del autoconcepto parece estar afectado, principalmente, por los efectos de comparación social. Este hallazgo no sólo confirma los resultados de investigaciones previas en el campo, sino que también contribuye a aclarar el papel de generor en el contexto interna / externa del modelo de referencia, en relación con el tema de la dimensión comparación en el dominio verbal, por lo menos.

Palabras clave: autoconcepto verbal comparación de dimensiones, estructura interna / externa de referencia del modelo, el género, el aprendizaje de lenguas extranjeras, contexto EFL. 


\section{Introduction}

The development of scholastic achievement appears to be substantially associated with the students' academic self-beliefs as they are derived from their academic expectancies and evaluations (Wigfield, Eccles, Schiefele, Roeser \& Davis-Kean, 2006). Among these self-beliefs the students' academic self-concept has beem evidenced as a cognitive-motivational key variable. In terms of self-perceptions and self-evaluations of one's own capabilities, it is multifaceted in nature and appears to be composed of distinct subconcepts - which in particular reflect the students' competence beliefs in a certain domain, subject, or with respect to a certain type of academic task (Byrne, 1996; Marsh \& O’Mara, 2008). These self-concept facets can be empirically separated. They are differentially correlated with corresponding performance variables and can explain a higher degree of achievement variances than, with regard to content, more general measures of academic self-concept (Möller, Pohlmann, Köller \& Marsh, 2009; Valentine, DuBois \& Cooper, 2004).

The formation of academic self-concepts can essentially be explained by individual information processing, in particular by the use of social, dimensional, and criterion-related information. Domain- or subject-specific self-concepts develop by social comparisons of one's own academic achievement with the outcomes of classmates (Dijkstra, Kuyper, van der Werf, Buunk \& van der Zee, 2008), by dimensional comparisons of one's own academic achievement in a certain domain or subject with the own outcomes in other domains or subjects, and by criterion-related comparisons of one's own academic achievement with decisive outcome standards in a specific domain or subject (Skaalvik \& Skaalvik, 2002).

The internal/external frame of reference model as presented by Marsh (1990) provides a theoretical perspective to explain the impact of social (external) and dimensional (internal) comparison processes on the formation of domain- or subject-specific self-concepts in academic settings. It assumes that the students' academic competence beliefs in a certain domain or subject are primarily affected by social comparison - that is, by perceiving their classmates mainly displaying worse, equal, or better outcomes. This social comparison shall lead to a substantially positive relationship between achievement and self-concept in a certain domain or subject. Moreover, students draw self-related conclusions from dimensional comparisons that is, by perceiving their outcomes across various domains or subjects as equal or different. This dimensional comparison can be made upward to an intraindividually stronger subject and 
then will result in a relatively lower self-concept - or it can be made downward to an intraindividually weaker subject and then will result in a relatively higher self-concept. Provided that the students really perceive their outcomes in various subjects as different (Rost, Sparfeldt, Dickhäuser \& Schilling, 2005; Skaalvik \& Rankin, 1992), this dimensional comparison shall lead to a substantially negative relationship between the achievement in a weaker subject and the self-concept in a stronger subject - and vice versa. This seems paradoxical because, at first glance, theoretically inexplicable negative associations between academic achievement and self-concept variables can be traced back to dimensional comparison processes. From a cognitive-motivational perspective, dimensional comparisons will affect the students' academic self-beliefs beyond external references and, therefore, will additionally contribute to influence their learning activities in each subject area. For instance, a student who believes a particular subject being weaker will possibly display a lowered level of engagement. Hence, in a certain educational setting students' academic self-perceptions do not only depend on the achievement feedback given by teacher.

In the past two decades an ample number of empirical studies have been able to largely support the predictions of the internal/external frame of reference model, which originally refers to the relations between verbal and math constructs. Across a wide range of age groups, school grades and educational settings there is consistent evidence for the subject-specific self-concepts of students to be dependent on social as well as on dimensional comparison effects (Möller, Pohlmann, Köller \& Marsh, 2009). The consistently replicated pattern of empirical findings raises the question of whether the model's conceptual scope can be extended to other academic domains or subjects. Altogether, the studies testing such extensions yielded somewhat mixed results - e.g. demonstrating negative as well as positive path coefficients between physical activities, mathematics and verbal subjects (Chanal, Sarrazin, Guay \& Boiché, 2009; Möller, Streblow, Pohlmann \& Köller, 2006). Those studies that had included additional subjects within a certain domain failed to verify any dimensional comparison effects. They rather pointed out that the achievement and self-concept variables between similar subjects within a certain domain were likely to correlate in a significantly positive manner, thus indicating small assimilative comparison effects (Dickhäuser, 2003; Dickhäuser, Reuter \& Hilling, 2005; Möller, Streblow, Pohlmann \& Köller, 2006; Schilling, Sparfeldt \& Rost, 2004). However, a cross-cultural analysis of the relations between self-concept and achievement in science and mathematics helps to draw a more differentiated picture. Across the most diverse range of countries from the TIMSS study, it demonstrated varying degrees of contras- 
ting or assimilative comparison effects and, therefore, indicated the impact of cultural differences on students' academic perceptions or ability beliefs (Chiu, 2008).

In particular, within the verbal domain some studies have analyzed the issue of dimensional comparison effects between the native (L1) and foreign (L2) language. Although sound evidence exists for the close connection between basic linguistic competencies in the L1 and foreign language acquisition (Dörnyei, 2005; Sparks \& Ganschow, 2001), so that the academic learning in both subjects are to be considered as rather similar, there is no reason to rule out the possibility that the students might perceive the academic tasks and outcomes, respectively, in the L1 and L2 in a different manner - and that their subject-specific self-concepts might also be affected by related dimensional comparisons. From this aspect, it might matter that, in foreign language learning classrooms, oral skills are assigned as more important and, thus, the students' competence beliefs in the L1 and L2 might yet reflect fairly different achievement experiences. The results from foreign language research at least point out that L2 learners, especially, reported those classroom situations as very challenging and critical elements in which oral language use is required (Brantmeier, 2005; Horwitz, 2001; MacIntyre, Dörnyei, Clément \& Noels, 1998). However, the whole current self-concept research on internal comparison processes within the verbal domain only yields few and inconsistent findings. Those studies, in which the relations between achievement and self-concept variables in the L1 German and the L2 English were considered mostly showed no significant path coefficients, thus indicating that neither contrasting nor assimilative effects existed between the two subjects (Dickhäuser, 2003; Möller, Streblow, Pohlmann \& Köller, 2006; Schilling, Sparfeldt \& Rost, 2004). On the other hand, one analysis revealed significant negative path coefficients between the achievement and self-concept variables in English and Spanish (Marsh \& Yeung, 2001). In this particular study, the student sample consisted of both Spanish and English native speakers, and the English achievement variable referred to all verbal school subjects. Through this, the result seemed to strongly confound either sample and method influences, and did not provide adequate evidence to support the occurrence of dimensional comparison effects within the verbal domain. Moreover, without such methodological limitations, in another research context significant negative path coefficients between the achievement and self-concept variables in Chinese (as a native language) and English (as a foreign language) had been repeatedly reported (Marsh, Kong \& Hau, 2001; Xu \& Marsh, 2009). Due to the fundamental differences between the two languages, this result appears to be very plausible in so far as the students' academic perceptions generally will emphasise the 
contrasting nature of related classroom requirements and achievement outcomes, respectively. Just recently, in a longitudinal investigation of preadolescent students' achievement and selfconcepts in German and French, significant negative relations between prior achievement and later self-concept variables have been found, thus indicating the formation of language-specific self-concepts are affected by the dimensional comparison processes (Brunner, Keller, Dierendonck, Reicher, Ugen, Fischbach \& Martin, 2010). This result evidently contributes to clarify the question of dimensional comparison effects within the verbal domain. But it cannot claim to substantiate such effects with regard to the native versus foreign language issue because, in the Luxembourgian school system, where the study has been conducted, German and French both are already taught simultaneously as official languages on the primary school level. Nevertheless, this result underlines the need for further research on the individual, social, and contextual determinants contrasting effects between similar language subjects.

Looking more closely at the relevant research findings, the school type or educational tracking level may figure as an important factor. Whereas those studies that cannot report any contrasting or assimilative comparison effects have been mainly conducted in classrooms from higher educational tracks, the Luxembourgian study has analyzed data from all educational tracks. Therefore, it would be worth clarifying whether intraindividually existing achievement differences between two similar verbal subjects are expected to be less common on higher educational tracking levels and more common on intermediate or lower educational tracking levels - and, thus, dimensional comparisons will be expected to appear differently across various school settings.

Furthermore, even within a certain educational track, the magnitude and direction of dimensional comparison effects might also be dependent on the students' gender as another differential determinant. Empirically, the females' superiority in verbal achievement domains is well proven (De Fraine, Van Damme \& Onghena, 2007; Gambell \& Hunter, 1999; Marsh, 1989; Schilling, Sparfeldt \& Rost, 2006; Skaalvik \& Rankin, 1994; Steinmayr \& Spinath, 2008). But this advantage does not appear to be consistently associated with higher verbal self-concepts in female learners. Although some studies showed higher verbal self-concepts for females (Brunner, Keller, Hornung, Reichert \& Martin, 2009; Byrne \& Shavelson, 1987; Dörnyei \& Clément, 2001; Hergovich, Sirsch \& Felinger, 2004; Ireson \& Hallam, 2009; Marsh \& Yeung, 1998; Schilling, Sparfeldt \& Rost, 2006; Wilgenbusch \& Merrell, 1999), other studies could not report any gender-dependent differences in verbal self-concepts 
(Helmke, Schrader, Wagner, Nold \& Schröder, 2008; Holder, 2005; Kurman, 2004; Skaalvik \& Skaalvik, 2004). The fact that apparent achievement differences do not seem to lead to corresponding self-concept differences possibly indicates a tendency for the males to overestimate and for the females to underestimate their verbal competencies, respectively (Bornholt, Goodnow \& Cooney, 1994). Accordingly, female and male learners should significantly differ in evaluating their verbal outcomes and, moreover, should carry out dimensional comparison processes in a different manner. Structural equation modeling procedures usually applied in the research field for the most part analyze total samples including both female and male students. Thus, in principle, they are prone to leave such gender-dependent differences in dimensional comparison effects undiscovered. There are only a few studies that have driven separate analyses for female and male samples. Though Skaalvik and Rankin (1990) could demonstrate dimensional contrasting effects between the verbal and math domain to amount for higher magnitude in the female subsample. In this study the self-concept variable has been operationalized in terms of task-specific self-efficacy expectancies, which are known to be hardly used for internal comparison (Marsh, Walker \& Debus, 1991). For that reason, the result did not offer conceptually sound evidence for gender-dependent differences in dimensional comparison effects on the level of subject-specific self-concepts. In another study, Abu-Hilal (2002) had calculated separate structural equation models for the male and female samples. As a result, he had found different path coefficients in the relationship between achievement and self-concept scores across the verbal and math domains. The girls' and boys' sample, however, rather differed in size and, moreover, the goodness of fit indices of structural equation solutions remained quite insufficient. From this aspect, the result does not allow to draw any valid conclusion. In contrast, the study conducted by Nagy, Trautwein, Baumert, Köller and Garrett (2006) was to be based on a more solid data sample and demonstrated the dimensional contrast effects between mathematics and biology to reach a stronger magnitude for boys. Between mathematics and German such differences did not appear (Brunner, Lüdtke \& Trautwein, 2008).

Altogether, these research findings lend some preliminary support to emerging genderdependent differences in the dimensional comparison processes. Further research should, therefore, definitely analyse the determination of this effect - e.g. concerning the type of school subjects, age or grade level influences, individual prerequisites, and the impact of the educational or classroom setting. In particular, with regard to the relations between achievement and self-concept constructs in the L1 and L2, such research efforts are entirely missing. 


\section{Aim of the present study}

From the perspective of the internal/external frame of reference model of self-concept development dimensional comparison, effects are primarily to be expected between rather different domains or subjects. Whether they may also determine the formation of self-concepts across similar verbal subjects such as the native and non-native (foreign) language seems empirically less clear. Relevant research findings mostly fail to demonstrate contrastive or assimilative comparison effects within the verbal domain, but some studies suggest the magnitude and direction of dimensional comparisons being differentially affected by certain contextual and individual factors - such as the educational tracking level, the students' age or grade level and, in particular, the students' gender. Against this background, the present study aims to analyze the secondary students' achievement and self-concepts within the verbal domain namely, concerning German as the native language and English as a foreign language. Using a structural equation modeling approach to the total sample as well as to the female and male subsample, it is intended to investigate (1) the occurance of dimensional comparison effects in the self-concept variables and (2) to test possible gender-dependent differences in the relations between achievement and self-concept variables across both subjects.

\section{Method}

\section{Participants}

The study was conducted with a sample of $N=256$ students (144 females, 112 males) from 20 ninth-grade grammar school classes of a large urban catchment. Their average age was 15.0 years $(S D=0.5)$. Their participation was on a voluntary basis and only with explicit parental consent. The predominant majority of participating students $(N=222)$ declared themselves to be born in Germany. With respect to the English and German achievement measures, the students who were not born in Germany did not significantly differ from their classmates (t-tests for independent samples: $p>.05$ ). The number of students stating English to be their family language was $n=1(0.4 \%)$, which was negligibly small.

\section{Variables and Measurements}

The academic self-concepts in the L1 German and the L2 English were assessed using 14 six-point Likert items for each language. They address the extent of subjective competence 
expectations with regard to meeting academic demands. In the majority, these questionnaire items originate from pertinent time-tested instruments, and they were presented in the economical grid style format (Baumert, Gruehn, Heyn, Köller \& Schnabel, 1997; Faber, 2007; Rost, Sparfeldt \& Schilling, 2007). The wording of the items for both langugage subjects was strictly parallel. No explicit social or dimensional comparisons were verbalized. Sample item: "I try hard in English, but I do not perform very well." It was possible to form two scales for measuring subject-specific self-concepts. The results of a confirmatory factor analysis using three item parcels (with 5+5+4 items) (Bandalos, 2002) showed an appropriate fit of the measurement model $\left(\chi^{2} / \mathrm{df}=1.211, \mathrm{TLI}=1.00, \mathrm{CFI}=1.00, \mathrm{RMSEA}=0.029\right)$.

Different indicators were used as for assessing academic achievement in each language subject. Concerning relevant competence aspects, the respective teaching persons were asked to complete a questionnaire consisting of seven rating items. In particular, they concerned the students' proficiency level in English and German - e.g., their competency in reading comprehension, spelling, grammar, oral language use, composition (Faber, 2009). In terms of principal components analysis, these subject-specific competence ratings could clearly be separated. Both factors could explain overall nearly $80 \%$ of the entire trait variance. The internal reliabilities turned out to be highly sufficient (Table 1). As additional performance information, the students' school latest grades in both subjects were assessed. In agreement with studies of this kind that cannot identify seriously biased limitations in the accuracy of judgment in comparable age groups these grades were self-reported by the students (Möller, Streblow, Pohlmann \& Köller, 2006). Gender was included as a dummy variable (coding: male $=1$, female $=2$ ) in the analyses.

\section{Procedure}

The self-belief and achievement data were gathered in the course of two class periods by two (advanced collegiate) test supervisors, respectively, who had been instructed in detail prior to the beginning of the test. This took place class for class and in the absence of the teaching staff. The teaching staff in charge collected additional competence data with corresponding questionnaires for German and English.

\section{Data Analyses}

For determining possible classroom effects on the variation of achievement and selfconcept variables, intraclass correlation coefficients (ICC) were calculated at first. They 
amounted for the teachers' competency ratings in German $\rho_{\mathrm{IC}}=.06$ and in English $\rho_{I C}=.09$, for the students' grades in German $\rho_{\mathrm{IC}}=.12$ and in English $\rho_{I C}=.09$, for the self-concept in German $\rho_{I C}=.07$ and in English $\rho_{I C}=.08$. Thus, the greatest part of achievement and selfconcept differences could be explained by variation on the students' individual level. In order to rule out even minor classroom effects, for all variables z-standardised scores within each class were used.

The relations between the achievement and self-concept constructs in the L1 German and the L2 English were analyzed by testing a structural equation model (Arbuckle \& Wothke, 1999; Byrne, 2010) in which the subject-specific achievement variables as exogenous and the subject-specific self-concepts as endogenous variables were included. The measurement model of the German and English self-concept variable each consisted of three item parcels (with 5+5+4 items). Similarly, the measurement model of the teacher competence ratings consisted of two item parcels (with $4+3$ items). Because the self-concept items were all identically worded, the error terms between the German and English construct operationalisations were allowed to correlate (Marsh, Martin \& Debus, 2001). Initially, structural equation analyses were calculated for the total sample. For further clarifying the potential effects of the gender variable in a second step, then, multiple group analyses were driven for both the teacher competence ratings and the school grades - each comparing an unconstrained moderator model and a fully constrained invariance model. Following conventional rules of thumb in structural equation modeling, a sufficient model fit should be achieved when the $\chi^{2} / d f$ value is lower than 3 , the $T L I$ is higher than .90 , the $C F I$ is higher than .90 , and the RMSEA is at least lower than or equal to .08 (Marsh, Balla \& Hau, 1996).

There were only few missing values among the self-concept items (amounting at most to $1.6 \%$ ). They were automatically replaced by means of maximum likelihood estimation available from the AMOS software (Enders \& Bandalos, 2001). The school report grades were complete.

\section{Results}

Table 1 shows the descriptive statistics and the reliabilities of the manifest achievement and self-concept variables, which appear to be sufficient. Furthermore, zero-order correlations were computed. As could theoretically be expected, they indicated the achievement and self-concept variables to be associated in a typically subject-specific manner. The achievement variables were clearly more strongly interrelated than the self-concept variables, 
and the relations between achievement and self-concept variables were stronger within a certain subject than across both subjects.

Additionally, mean differences between both subjects were analyzed using t-tests for paired samples. Neither for the German nor for the English subject significant achievement and self-concept differences could be found. Hence, in the total sample, the students seemed to experience intraindividually contrasting achievement levels across both subjects, if at all, only to a minor extent.

Table 1. Descriptive statistics and reliabilities of manifest variables, differences between subjects, and zero-order correlations.

\begin{tabular}{rcccccc}
\hline & SCGE & SCEN & TCRGE & TCREN & GRGE & GREN \\
\hline Items & 14 & 14 & 7 & 7 & 1 & 1 \\
$M$ & 60.3 & 58.8 & 29.1 & 28.7 & 3.1 & 3.1 \\
$S D$ & 13.9 & 14.7 & 6.3 & 6.4 & 0.9 & 0.9 \\
Cronbach's Alpha & .94 & .92 & .95 & .95 & & \\
Differences & $t=0.31, p=0.975$ & $t=-1.44, p=0.153$ & $t=.00, p=1.000$ \\
SCGE & & .39 & .67 & .34 & .65 & .37 \\
SCEN & & .35 & .58 & .34 & .71 \\
TCRGE & & & .53 & .77 & .58 \\
TCREN & & & & .51 & .71 \\
GRGE & & & & & & .56 \\
\hline
\end{tabular}

Significance: All coefficients $p \leq .001$

Note . SCGE = self-concept in German, SCEN = self-concept in English, GRGE = latest grade in German, GREN = latest grade in English, TCRGE = teacher competency ratings in German, TCREN $=$ teacher competency ratings in English .

Likewise, t-tests for independent samples were run for gender differences in the total sample. As a result, the girls showed significant higher scores in the German achievement and self-concept variable. The corresponding effect size was stronger for the school report grades, thus indicating that the girls' self-concept did not fully reflect their advantage in achievement. In the English achievement and self-concept variable no significant differences occurred (Table 2). To summarize, within the verbal domain gender differences only referred to the native language. 
Table 2: Gender differences among self-concept and competency measures in the English and German language subject.

\begin{tabular}{|c|c|c|c|c|c|c|}
\hline & \multicolumn{2}{|c|}{ Males } & \multicolumn{2}{|c|}{ Females } & \multirow[b]{2}{*}{$t$} & \multirow[b]{2}{*}{$d$} \\
\hline Variables & $M$ & $S D$ & $M$ & $S D$ & & \\
\hline Self-concept in Englisch & 59.1 & $(12.3)$ & 58.6 & $(16.4)$ & 0.283 & 0.03 \\
\hline Self-concept in German & 56.2 & $(12.7)$ & 63.5 & $(12.4)$ & $-4.613 * * *$ & -0.57 \\
\hline $\begin{array}{l}\text { Teacher competency ra- } \\
\text { tings English }\end{array}$ & 28.9 & $(5.3)$ & 29.6 & $(6.8)$ & -0.821 & 0.11 \\
\hline $\begin{array}{l}\text { Teacher competency ra- } \\
\text { tings German }\end{array}$ & 27.0 & $(6.2)$ & 31.3 & $(6.0)$ & $-4.714 * * *$ & -0.70 \\
\hline $\begin{array}{l}\text { English (self-reported) } \\
\text { grades }\end{array}$ & 3.0 & $(0.8)$ & 3.2 & $(0.9)$ & 1.590 & 0.11 \\
\hline $\begin{array}{l}\text { German (self-reported) } \\
\text { grades }\end{array}$ & 2.8 & $(0.8)$ & 3.4 & $(0.8)$ & $5.660 * * *$ & -0.75 \\
\hline
\end{tabular}

Significance: $* * * p \leq .001$

Note. $\mathrm{M}=$ Arithmetic mean, $\mathrm{SD}=$ standard deviation, $\mathrm{t}=\mathrm{t}$-value, $\mathrm{d}=$ effect size .

Table 3: Differences between English and German variables dependent on gender.

\begin{tabular}{lcccccccc}
\hline & Males & \multicolumn{1}{c}{ Females } \\
& $\mathrm{MD}$ & $\mathrm{t}$ & $\mathrm{p}$ & $\mathrm{d}$ & $\mathrm{MD}$ & $\mathrm{t}$ & $\mathrm{p}$ & $\mathrm{d}$ \\
\hline $\begin{array}{l}\text { Self-concept } \\
\begin{array}{l}\text { English-German } \\
\text { Teacher competency ratings }\end{array}\end{array}$ & 2.45 & 1.717 & .089 & 0.17 & $-4,99$ & -3.769 & .000 & 0.32 \\
$\begin{array}{l}\text { English-German } \\
\begin{array}{l}\text { (Self-reported) grades } \\
\text { English-German }\end{array}\end{array}$ & 0.85 & 1.427 & .158 & 0.17 & -3.02 & -3.905 & .000 & 0.45 \\
\hline
\end{tabular}

Note. $\mathrm{MD}=$ Mean difference, $\mathrm{t}=\mathrm{t}-\mathrm{value}, \mathrm{p}=$ probability, $\mathrm{d}=$ effect size.

However, for further clarification of multiple mean differences between subjects ttests for matched samples were separately computed in each gender group (using an adjusted p-value of .0083). Their results could substantially differentiate the preliminary findings for the whole sample. In the male subsample intraindividually existing differences between English and German self-concepts were not statistically significant, whereas the differences in self-reported grades appeared to be statistically significant - though relatively low in magnitude (Table 3). Compared with this, in the female subsample all mean differences between English and German variables appeared to amount higher on a statistically significant probability level. Thus, the female self-perceptions clearly reflected their higher proficiency in the 
L1 German. The male self-perceptions did not really reflect their lower proficiency in the L1 German. Interestingly, teacher competence ratings indicated differences across both subjects for the females, but not for the males.

On that basis, the structural equation modeling analyses for the total sample, as they were separately calculated with respect to the teacher ratings and school grades, did not reveal any unexpected results (Figure 1,2). Within each subject there were strong and statistically significant path coefficients from the achievement to the self-concept variable. The corresponding path coefficients across both subjects were small and statistically non-significant. Thus, social comparison effects might primarily explain the interindividual variance in the subjectspecific self-concepts. Neither contrasting nor assimilative effects across subjects could be demonstrated. The goodness of fit indices of this "external frame of reference" solution all reached an appropriate value.

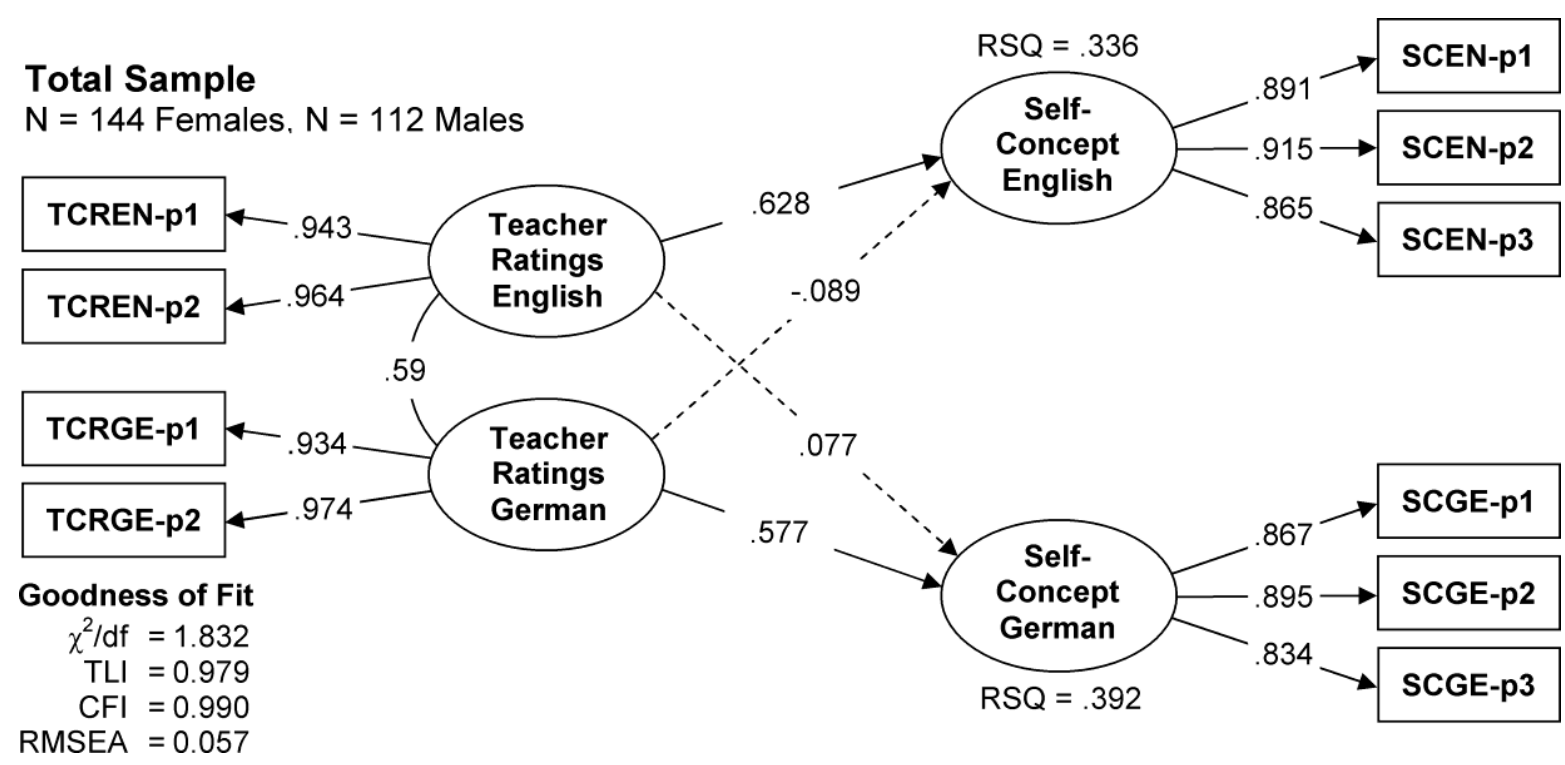

Figure 1. Relations between teacher competency ratings and self-concept in German and English: Structural equation modeling results for the total sample $(p=$ item parcels, $R S Q=$ squared multiple regression coefficients). Solid lines represent significant path-coefficients, dashed lines nonsignificant path-coefficients. 


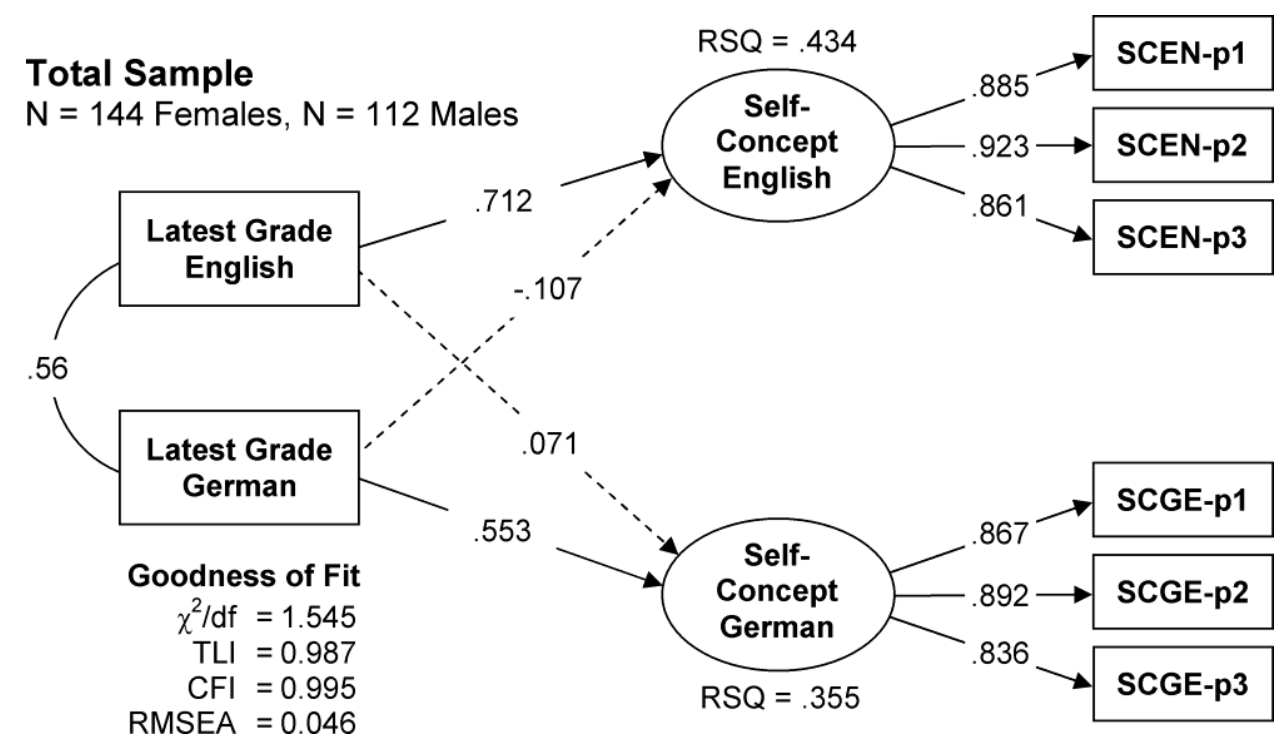

Figure 2. Relations between latest grades and self-concept in German and English: Structural equation modeling results for the total sample $(p=$ item parcels, RSQ $=$ squared multiple regression coefficients). Solid lines represent significant path-coefficients, dashed lines nonsignificant path-coefficients.

Furthermore, the results of multigroup analyses could not substantiate any moderating effect of the gender variable. Comparing the unconstrained moderator model and the constrained invariance model there were no significant fit differences with respect to both the teacher competence ratings and the latest school grades (Table 4). Therefore, the relations between achievement and self-concept variables across the L1 and L2 language subjects appeared not to be substantially affected by the learners' gender and could be best explained by means of the invariance model.

Table 4: Comparison of multiple group analyses: Fit indices, differences, and significance of differences.

\begin{tabular}{lccccccc}
\hline Competence Ratings & $\chi^{2} / \mathrm{df}$ & TLI & CFI & RMSEA & $\Delta \chi^{2}$ & $\Delta \mathrm{df}$ & $\mathrm{p}$ \\
\hline Moderator Model & 1.506 & 0.975 & 0.988 & 0.045 & \multirow{2}{*}{1.15} & 9 & .265 \\
Invariance Model & 1.467 & 0.977 & 0.987 & 0.043 & & & \\
\hline Latest Grades & $\chi^{2} / \mathrm{df}$ & TLI & CFI & RMSEA & $\Delta \chi^{2}$ & $\Delta \mathrm{df}$ & $\mathrm{p}$ \\
\hline Moderator Model & 1.070 & 0.997 & 0.999 & 0.017 & \multirow{2}{*}{11.34} & 9 & .253 \\
Invariance Model & 1.119 & 0.995 & 0.997 & 0.022 & & & \\
\hline
\end{tabular}




\section{Discussion}

In the present study, the assumptions of the internal/external frame of reference model were tested within the verbal domain, thus, considering the relations between the achievement and self-concept variables in two similar language subjects. Although previous research in this field often failed to demonstrate contrastive or assimilative comparison effects within the verbal domain, some empirical findings suggested the magnitude and direction of dimensional comparisons being differentially affected by students' gender. The aim of this study was, therefore, to investigate possible gender-dependent differences in dimensional comparison effects relating to German (as the native language) and English (as a foreign language). The results of structural equation modeling analyses could not yield any evidence for dimensional comparison effects across both language subjects. They also could not support the assumption of substantial gender-dependent relations among constructs. Altogether, interindividually existing differences in subject-specific self-concepts could be mainly explained by social comparison effects.

Concerning the scope of the internal/external frame of reference model within the verbal domain, these findings clearly confirm recent research results in the field (Dickhäuser, 2003; Möller, Streblow, Pohlmann \& Köller, 2006; Schilling, Sparfeldt \& Rost, 2004). Despite the females' higher proficiency and self-perceptions in German there were neither contrasting nor assimilative effects in the relations between L1 and L2 constructs - indicating that all students seemingly perceived their competencies in both subjects in an independent manner. Hence, their motivational beliefs should not operate across both languages. Especially in the case of the female students, their significantly different perceptions of own English and German competencies did not have any impact on the relations among variables. But before approaching any theoretically valid conclusion, these results need to be further replicated and refined. In order to overcome one limitation of the present study, such replication studies should be run with greater sample size from more than one grade level. They should also analyze the role of gender in dimensional comparison processes with regard to other cultural contexts and educational settings (Chiu, 2008). They should, in particular, combine other L1 language subjects with the L2 English in order to test the generalizability of the present findings (Marsh \& Yeung, 2001). 
Related research efforts should strive for comprehensive insights into the relations between achievement and self-concept constructs within the verbal domain - however, also considering the role of gender. With respect to the processing of external comparison information the students' use of within-gender references deserves further attention. In particular, if the female students would typically prefer female classmates for estimating their academic standing in an educational setting, they would disregard their advantage in the native language (Thijs, Verkuyten \& Helmond, 2010). With respect to the processing of internal comparison information it should be worthwhile to exactly analyze the predominance and determination of dimensional upward versus downward comparisons between two similar language subjects. Due to the limitations of the structural equation modeling method, the issue of upward vs. downward comparisons can be best verified in experimental research approaches (Pohlmann \& Möller, 2009). Possibly the magnitude and direction of constrasting or assimilation effects may differ among more or less competent learners. Analyses of mean variances across gender and achievement level should provide more information about the nature of dimensional comparisons in the formation of verbal self-concepts (Möller \& Pohlmann, 2010). Additonally, it would be interesting to also use qualitative research methods. They could help to thoroughly explore the individually relevant information (e.g. consensus or consitency information) students realize when considering intraindividually different achievement outcomes (Kelley \& Michela, 1980; Skaalvik \& Skaalvik, 2002). With this reservation, it would be then reasonable to gain more insight into the meaning of comparative information processing for the formation of students' self-concepts in the L1 and L2 subjects - and to determine its contribution to an incremental understanding of students' cognitive-motivational functioning in the EFL context (Gabillon, 2005; Mercer, 2011).

Lastly, further analyses of dimensional comparison effects within the verbal domain should also take into account, that the achievement and self-concept constructs within the verbal domain can be further differentiated. Accordingly, educational self-concept research has already yielded consistent evidence to divide the academic self-concept in a foreign language into several subcomponents (Holder, 2005; Laine, 1988; Lau, Yeung, Jin \& Low, 1999). These subcomponents are shown to incrementally explain interindividual variance in students' verbal achievement. Further analyses of dimensional comparison effects within the verbal domain should include such subcomponents and clarify their role in students' selfrelated information processing (Mercer, 2011) - thus, reaching for another differentiation of the internal/external frame of reference model across similar verbal subjects. 


\section{References}

Abu-Hilal, M.M. (2002). Frame of reference model of self-concept and locus of control: A cross gender study in the United Arab Emirates. Paper presented at the 87th Annual Convention of the American Educational Research Association, New Orleans, April 1$5,2002$.

Arbuckle, J.L. \& Wothke, W. (1999). Amos 4.0 user's guide. Chicago: SmallWaters Corporation.

Bandalos, D.L. (2002). The effects of item parceling on goodness-of-fit and parameter estimate bias in structural equation modeling. Structural Equation Modeling, 9, 78-102.

Baumert, J., Gruehn, S., Heyn, S., Köller, O. \& Schnabel, K. (1997). Bildungsverläufe und psychosoziale Entwicklung im Jugendalter (BIJU). Band 1: Welle 1-4 [Academic and psychosocial development during adolescence]. Berlin: Max-Planck-Institut für Bildungsforschung.

Bornholt, L.J., Goodnow, J.J. \& Cooney, G.H. (1994). Influences of gender stereotypes on adolescents' perceptions of their own achievement. American Educational Research Journal, 31, 675-692.

Brantmeier, C. (2005). Anxiety about L2 reading or L2 reading tasks? A study with advanced language learners. The Reading Matrix, 5, 67-85.

Brunner, M., Keller, U., Dierendonck, C., Reichert, M., Ugen, S., Fischbach, A. \& Martin, R. (2010). The structure of academic self-concept revisited: The nested Marsh/Shavelson model. Journal of Educational Psychology, 102, 964-981.

Brunner, M., Keller, U., Hornung, C., Reichert, M. \& Martin, R. (2009). The cross-cultural generalizability of a new structural model of academic self-concept. Learning and Individual Differences, 19, 387-403.

Brunner, M., Lüdtke, O. \& Trautwein, U. (2008). The internal/external frame of reference model revisited: Incorporating general cognitive ability and general academic selfconcept. Multivariate Behavioral Research, 43, 137-172.

Byrne, B.M. (1996). Academic self-concept: Its structure, measurement, and relation to academic achievement. In B.A. Bracken (Ed.), Handbook of self-concept. Developmental, social, and clinical considerations (pp. 287-316). New York: Wiley.

Byrne, B.M. (2010). Structural equation modeling with AMOS: Basic concepts, applications, and programming (2nd ed.). New York: Routledge. 
Byrne, B.M. \& Shavelson, R.J. (1987). Adolescent self-concept: Testing the assumption of equivalent structure across gender. American Educational Research Journal, 24, 365385 .

Chanal, J.P., Sarrazin, P.G., Guay, F. \& Boiché, J. (2009). Verbal, mathematics, and physical education self-concepts and achievements: An extension and test of the internal/external frame of reference model. Psychology of Sport and Exercise, 10, 61-66.

Chiu, M.-S. (2008). Achievements and self-concepts in a comparison of math and science: exploring the internal/external frame of reference model across 28 countries. Educational Research and Evaluation, 14, 235-254.

De Fraine, B., Van Damme, J. \& Onghena, P. (2007). A longitudinal analysis of gender differences in academic self-concept and language achievement: A multivariate multilevel latent growth approach. Contemporary Educational Psychology, 32, 132-150.

Dickhäuser, O. (2003). Überprüfung des erweiterten Modells des internal/external frame of reference [Testing an extended version of the internal/external frame of reference model]. Zeitschrift für Entwicklungspsychologie und Pädagogische Psychologie, 35, 200-207.

Dickhäuser, O., Reuter, M. \& Hilling, C. (2005). Coursework selection: A frame of reference approach using structural equation modeling. British Journal of Educational Psychology, 75, 673-688.

Dijkstra, P., Kuyper, H., van der Werf, G., Buunk, A.P. \& van der Zee, Y.G. (2008). Social comparison in the classroom: A review. Review of Educational Research, 78, 828879 .

Dörnyei, Z. (2005). The psychology of the language learner. Individual differences in second language acquisition. New York: Routledge.

Dörnyei, Z. \& Clément, R. (2001). Motivational characteristics of learning different target languages: Results of a nationwide survey. In Z. Dörnyei \& R. Schmidt (Eds.), Motivation and second language acquisition. Technical Report \#23 (pp. 399-432). Honululu, University of Hawai'i: Second Language Teaching and Curriculum Center.

Enders, C.K. \& Bandalos, D.L. (2001). The relative performance of full information maximum likelihood estimation for missing data in structural equation models. Structural Equation Modeling, 8, 430-457.

Faber, G. (2007). Academic self-beliefs in the spelling domain: Empirical research findings on elementary school students' subject-specific self-concept, causal attributions, and test anxiety. In E.M. Vargios (Ed.), Educational Psychology Research Focus (pp. 65- 
120). New York: Nova Science Publishers.

Faber, G. (2009). Die Erfassung kognitiv-motivationaler Lernermerkmale gegen Ende der gymnasialen Sekundarstufe I. Ergebnisse aus einem interdisziplinären Forschungsprojekt zur mündlichen Erzählkompetenz in Englisch [Measuring academic self-beliefs in secondary foreign language learners: Findings from an interdisciplinary study on EFL learners' oral narrative competencies]. Zeitschrift für Fremdsprachenforschung, 20, $179-212$.

Gabillon, Z. (2005). L2 learner's beliefs: An overview. Journal of Language and Learning, 3, 233-260.

Gambell, T.J. \& Hunter, D.M. (1999). Rethinking gender differences in literacy. Canadian Journal of Education, 24, 1-16.

Helmke, A., Schrader, F.-W., Wagner, W., Nold, G. \& Schröder, K. (2008). Selbstkonzept und Motivation im Fach Englisch [Self-concept and motivation in learning English as a foreign language]. In DESI-Konsortium (Hrsg.), Unterricht und Kompetenzerwerb in Deutsch und Englisch. Ergebnisse der DESI-Studie (S. 244-257). Weinheim: Beltz.

Hergovich, A., Sirsch, U. \& Felinger, A. (2004). Gender differences in the self-concept of preadolescent children. School Psychology International, 25, 207-222.

Holder, M.C. (2005). Fähigkeitsselbstkonzept und Leistungsmotivation im Fremdsprachenunterricht [Competence beliefs and academic motivation in the EFL context]. Bern: Lang.

Horwitz, E.K. (2001). Language anxiety and achievement. Annual Review of Applied Linguistics, 21, 112-126.

Ireson, J. \& Hallam, S. (2009). Academic self-concepts in adolescence: Relations with achievement and ability grouping in schools. Learning and Instruction, 19, 201-213.

Kelley, H.H. \& Michela, J.L. (1980). Attribution theory and research. Annual Review of Psychology, 31, 457-501.

Kurman, J. (2004). Gender, self-enhancement, and self-regulation of learning behaviors in junior high school. Sex Roles, 50, 725-735.

Laine, E.J. (1988). The affective filter in foreign language learning and teaching. Report 2: A validation study of filtering factors with a focus on the learner's FL self-concept. Jyvaskyla University, Department of English: Jyvaskyla Cross-Language Studies, No. 15.

Lau, I.C., Yeung, A.S., Jin, P. \& Low, R. (1999). Toward a hierarchical, multidimensional English self-concept. Journal of Educational Psychology, 91, 747-755. 
MacIntyre, P.D., Dörnyei, Z., Clément, R. \& Noels, K.A. (1998). Conceptualizing willingness to communicate in a L2: A situational model of L2 confidence and affiliation. Modern Language Journal, 82, 545-562.

Marsh, H.W. (1989). Sex differences in the development of verbal and mathematics constructs: The high school and beyond study. American Educational Research Journal, 26, 191-225.

Marsh, H.W. (1990). Influences of internal and external frames of reference on the formation of math and English self-concepts. Journal of Educational Psychology, 82, 107-116.

Marsh, H.W., Balla, J.R. \& Hau, K.T. (1996). An evaluation of incremental fit indices: A clarification of mathematical and empirical processes. In G.A. Marcoulides \& R.E. Schumacker (Eds.), Advanced structural equation modeling techniques (pp. 315-353). Hillsdale: Erlbaum.

Marsh, H.W., Kong, C.-K. \& Hau, K.-T. (2001). Extension of the internal/external frame of reference model of self-concept formation: Importance of native and nonnative languages for Chinese students. Journal of Educational Psychology, 93, 543-553.

Marsh, H.W., Martin, A.J. \& Debus, R. (2001). Individual differences in verbal and math selfperceptions: One factor, two factors, or does it depend on the construct? In R.J. Riding \& S.G. Rayner (Eds.), Self perception. International perspectives on individual differences, volume 2 (pp. 149-170). Westport: Ablex.

Marsh, H.W. \& O’Mara, A.J. (2008). Self-concept is as multidisciplinary as it is multidimensional. A review of theory, measurement, and practice in self-concept research. In H.W. Marsh, R.G. Craven \& D.M. McInerney (Eds.), Self-processes, learning, and enabling human potential. Dynamic new approaches (pp. 87-115). Charlotte: Information Age Publishing.

Marsh, H.W., Walker, R. \& Debus, R. (1991). Subject-specific components of academic selfconcept and self-efficacy. Contemporary Educational Psychology, 16, 331-345.

Marsh, H.W. \& Yeung, A.S. (1998). Longitudinal structural equation models of academic self-concept and achievement: Gender differences in the development of math and English constructs. American Educational Research Journal, 35, 705-738.

Marsh, H.W. \& Yeung, A.S. (2001). An extension of the internal/external frame of reference model: A response to Bong (1998). Multivariate Behavioral Research, 36, 389-420.

Mercer, S. (2011). Towards an understanding of language learner self-concept. Dordrecht: Springer.

Möller, J. \& Pohlmann, B. (2010). Achievement differences and self-concept differences: 
Stronger associations for above or below average students? British Journal of Educational Psychology, 80, 435-450.

Möller, J., Pohlmann, B., Köller, O. \& Marsh, H.W. (2009). A meta-analytic path analysis of the internal/external frame of reference model of academic achievement and academic self-concept. Review of Educational Research, 79, 1129-1167.

Möller, J., Streblow, L., Pohlmann, B. \& Köller, O. (2006). An extension to the internal/external frame of reference model to two verbal and numerical domains. European Journal of Psychology of Education, 21, 467-487.

Nagy, G., Trautwein, U., Baumert, J., Köller, O. \& Garrett, J. (2006). Gender and course selection in upper secondary education: Effects of academic self-concept and intrinsic value. Educational Research and Evaluation, 12, 323-345.

Pohlmann, B. \& Möller, J. (2009). On the benefit of dimensional comparisons. Journal of Educational Psychology, 101, 248-258.

Rost, D.H., Sparfeldt, J.R., Dickhäuser, O. \& Schilling, S.R. (2005). Dimensional comparisons in subject-specific academic self-concepts and achievements: A quasi-experimental approach. Learning and Instruction, 15, 557-570.

Rost, D.H., Sparfeldt, J.R. \& Schilling, S.R. (2007). DISK-Gitter mit SKSLF-8. Differentielles Selbstkonzept-Gitter mit Skala zur Erfassung des Selbstkonzepts schulischer Leistungen und Fähigkeiten [The self-concept grid: A questionnaire for measuring facets of academic self-concept]. Göttingen: Hogrefe.

Schilling, S.R., Sparfeldt, J.R. \& Rost, D.H. (2004). Wie generell ist das Modell? Analysen zum Geltungsbereich des „Internal/External Frame of Reference“-Modells [On the generalizability of the internal/external frame of reference model]. Zeitschrift für Pädagogische Psychologie, 18, 221-230.

Schilling, S.R., Sparfeldt, J.R. \& Rost, D.H. (2006). Facetten des schulischen Selbstkonzepts. Welchen Unterschied macht das Geschlecht? [Does gender make a difference in students' academic self-concepts?] Zeitschrift für Pädagogische Psychologie, 20, 9-18.

Skaalvik, E.M. \& Rankin, R.J. (1990). Math, verbal, and general academic self-concept: The internal/external frame of reference model and gender differences in self-concept structure. Journal of Educational Psychology, 82, 546-554.

Skaalvik, E.M. \& Rankin, R.J. (1992). Math and verbal achievement and self-concepts: Testing the internal/external frame of reference model. Journal of Early Adolescence, 12, 267-279.

Skaalvik, E.M. \& Rankin, R.J. (1994). Gender differences in mathematics and verbal achieve- 
ment, self-perception and motivation. British Journal of Educational Psychology, 84, 419-428.

Skaalvik, E.M. \& Skaalvik, S. (2002). Internal and external frames of reference for academic self-concept. Educational Psychologist, 37, 233-244.

Skaalvik, S. \& Skaalvik, E.M. (2004). Gender differences in math and verbal self-concept, performance expectations, and motivation. Sex Roles, 50, 241-252.

Sparks, R.L. \& Ganschow, L. (2001). Aptitude for learning a foreign language. Annual Review of Applied Linguistics, 21, 90-111.

Steinmayr, R. \& Spinath, B. (2008). Sex differences in school achievement: What are the roles of personality and achievement motivation? European Journal of Personality, 22, 185-209.

Thijs, J., Verkuyten, M. \& Helmond, P. (2010). A further examination of the big-fish-littlepond effect: Perceived position in class, class size, and gender comparisons. Sociology of Education, 83, 333-345.

Valentine, J.C., DuBois, D.L. \& Cooper, H. (2004). The relation between self-beliefs and academic achievement: A meta-analytic review. Educational Psychologist, 39, 111-133.

Wigfield, A., Eccles, J.S., Schiefele, U., Roeser, R.W. \& Davis-Kean, P. (2006). Development of achievement motivation. In N. Eisenberg (Ed.), Handbook of child psychology. Volume 3: Social, emotional, and personality development (6th ed., pp. 933-1002). New York: Wiley.

Wilgenbusch, T. \& Merrell, K.W. (1999). Gender differences in self-concept among children and adolescents: A meta-analysis of multidimensional studies. School Psychology Quarterly, 14, 101-120.

$\mathrm{Xu}, \mathrm{M}$. \& Marsh, H. (2009). The internal/external frame of reference models of academic self-concept among three school subjects for Hong Kong adolescents: The role of native and foreign languages. Paper presented at the 5th International Biennial SELF Research Conference. Enabling human potential: The centrality of self and identity. Dubai, January 13-15, 2009. 
Günter Faber

[This page intentionally left blank] 